Int. J. Morphol.,

29(3):895-898, 2011.

\title{
The Correlation of Esophageal Body Length with Measure of External Body Parameters
}

\author{
Correlación de la Longitud del Cuerpo Esofágico con Medida de Parámetros Corporales Externos
}

"Wyckliffe Kaisha Otsianyi; "**Thomas Mutie \& ${ }^{* * * *}$ Kioko H. M.

KAISHA, O. W.; MUTIE, T. \& KIOKO, H. M. The correlation of Esophageal body length with measure of external body parameters. Int. J. Morphol., 29(3):895-898, 2011.

SUMMARY: There is disagreement as to whether there is a correlation between esophageal body length and that of various measurable external body parameters. This length has also been noted to vary in various disease states of the upper gastrointestinal tract and among various races. To our knowledge no such study has been published amongst an African population and Kenyans in particular. The purpose of this study was to determine how the length of the esophagus correlates with various external body parameters. This was a cross-sectional observational study at the endoscopy unit of Kenyatta National Hospital (KNH). All consenting patients undergoing upper gastrointestinal endoscopy (OGD) at $\mathrm{KNH}$. 76 subjects undergoing flexible esophagoscopy were evaluated. 43 were male. The mean esophageal length was $22.2 \mathrm{~cm}$ (SD 2.63). Males had a longer esophagus than women. The esophageal length had a negative correlation with weight of individual and body mass index. There was a positive correlation between esophageal length versus height of the individual and the sternal length. Individual's height is the parameter that best correlates with the esophageal body length.

KEY WORDS: Esophageal length; Sternal length; Body parameters.

\section{INTRODUCTION}

Esophageal length is known to vary from person to person, across age and gender groups (Song et al., 1991; Yang et al., 2005). Its length is also affected by various disease states of the upper gastrointestinal tract (Marshall $e t$ al., 1999).

Review of published literature reveals a wide variation regarding the length of the esophagus amongst different populations (Song et al., 1991; Scapa et al., 1997; Li et al., 1994; Awad et al., 1999; Yau et al., 2007). This may suggest a racial and ethnic difference in the length of the esophagus.

Various authors have attempted to correlate the esophageal length with various measurable body parameters such as individual's height, weight, age. Most agree that the individual's height best correlates with esophageal length (Song et al.; Yang et al.; Scapa et al.; Li et al.; Awad et al.; Yau et al.; Staiano \& Clouse, 1991). However there is disagreement about the other parameters, with some authors suggesting no correlation exists (Yang et al., 2005; Scapa et al.; Li et al.; Awad et al.).

The length of the sternum has been morphometrically correlated to the height of the individual. Teige (1983) observed that one's body height may be determined by Xrays of the human sternum if a wide dispersion is given. The given relations and formulae were valid only when measuring the sterna of adults. One can then infer that if as suggested that esophageal length correlates with body height, while body height correlates with sternal height then probably sternal height could be correlated with esophageal length.

The aim of this study was to determine whether there is a correlation between esophageal length and individual's parameters such as height, weight, body mass index and gender. In addition we attempted to correlate esophageal length with individuals' sternal length which has not been reported before.

\footnotetext{
* Lecturer, Department of Human Anatomy, School of Medicine, University of Nairobi, Kenya.

** M.Sc Gastroenterology (Lon). Consultant Physcian/ Gastroenterologist, Kenyatta National Hospital.

${ }^{* * *}$ Gastroenterology (Witts, S.A). Consultant Physcian/ Gastroenterologist, Kenyatta National Hospital.
} 


\section{MATERIAL AND METHOD}

We conducted a prospective study at Kenyatta National Hospital (KNH) Endoscopy Unit. The study was carried out among all consenting patients undergoing esophagogastroduodenoscopy. Those excluded were: patients in whom the standing height could not be achieved for reasons of disease or deformity, those in whom esophageal length could not be assessed for reasons of technicality or disease, those who had undergone surgery of the upper Gastrointestinal tract ( from the esophagus up to the suspensory ligament of the duodenum).

Ethical approval was sought from KNH research Ethics committee. Informed consent was obtained and patient's demographics were abstracted. The patient's weight was determined and standing height (heel to vertex) recorded. Using a tape measure the length of sternum was determined from the highest point of the suprasternal notch to the xiphoid process.

The esophageal length was then determined using a flexible endoscope. The length was considered to be the distance from the cricopharyngeal sphincter (as determined endoscopically) to the distal limit of the lower esophageal sphincter. Two readings were taken and an average was recorded. Further gastroduodenoscopy was completed and a recording of the diagnosis made. Where no lesion was seen in the esophagus, stomach and duodenum, the esophagus was then classified as normal.
The data was then analyzed using student's $t$ test for comparing the means. Correlation of the esophageal body length with various parameters was done using a Pearson's correlation test.

\section{RESULTS}

A total of 77 subjects were studied, of whom 43 were male. The mean esophageal length was $22.2 \mathrm{~cm}$ with a standard deviation of 2.63. The subjects demographics are summarized in Table I below.

Table I. Morphometric characteristics of patients.

\begin{tabular}{lcc}
\hline Factor & Mean $(\mathbf{\pm S E})$ & SD \\
\hline Height (in CM) & $164.73(1.04)$ & 9.12 \\
Weight (in Kgs) & $61.58(1.42)$ & 12.43 \\
Sternal length $(\mathrm{CM})$ & $19.74(0.23)$ & 2.05 \\
Esophageal length & $22.2(0.30)$ & 2.63 \\
\hline
\end{tabular}

SE: standard error; SD: standard deviation.

Length vs Sex. The male esophagus was relatively longer than female with a mean length of $22.7 \mathrm{~cm}$ (standard deviation or SD 1.84) compared to a female mean length of 21.6 (SD 3.32). This difference was just short of statistical significance $\mathrm{p}=0.076$.

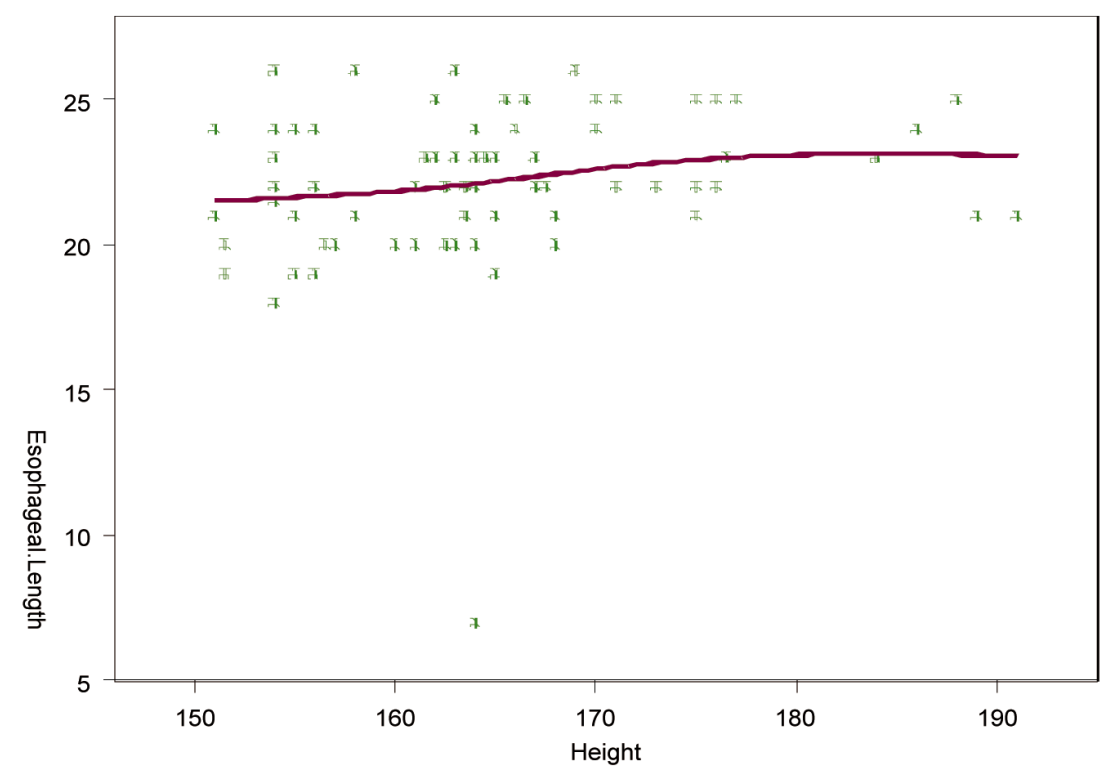

Fig. 1. Correlation of esophageal length with individuals' height.
Length vs Body weight, height and BMI. There was a negative correlation between the esophageal length with individuals' body weight with a Pearson's correlation coefficient of 0.156 . The correlation with ones body height was found to be positive and moderate with a Pearson's correlation coefficient of 0.43 . The Skater plot is shown in figure 1 below. Calculated versus the body mass index the correlation coefficient was -0.237 .

Length vs sternal length. The mean length of the sternum was 19.74 (SD 2.05). The correlation between the esophageal length and the sterna though positive was weak with a Pearson correlation coefficient of 0.153 . 


\section{DISCUSSION}

The esophagus is a muscular canal, about 23 to 25 $\mathrm{cm}$ long, extending from the pharynx to the stomach (Bannister, 2000). It begins in the neck at the lower border of the cricoid cartilage, opposite the sixth cervical vertebra, descends along the front of the vertebral column, through the superior and posterior mediastinum, passes through the diaphragm, and, entering the abdomen, ends at the cardiac orifice of the stomach, opposite the eleventh thoracic vertebra.

The classical descriptions of esophageal anatomy in textbooks state that the esophagus is 10 inches or $25 \mathrm{~cm}$ long (Marshall et al.; Bannister). However, these dimensions are based on cadaveric measurements which may be influenced by post-mortem changes (Bannister).

Various authors have published different lengths for the esophagus among adults. Among adults Li et al. found the average esophageal length to be $22.9+/-0.2 \mathrm{~cm}$ in subjects without disease. In this study esophageal length was taken to be the difference between the high pressure zone of the upper esophageal sphincter and proximal margin of the lower esophageal sphincter.

Awad et al. in a similar study documented the length of the esophagus to be $28.3+/-2.41 \mathrm{~cm}$. The length of the esophagus was defined as the distance between the proximal end of the upper esophageal sphincter and the distal end of the lower esophageal sphincter. Yau et al. in a study using manometric measurements found that the mean esophageal length was $23 \mathrm{~cm}$ (range 14 to $30 \mathrm{~cm}$ ).

The above studies therefore show considerable variation in length despite different methods and landmark points being used. Our findings add to those of the authors above and demonstrate considerable variation in length of esophagi among different populations. It thus emphasizes the need of availability of local anthropometric measures in interpretations of various body parameters in clinical and forensic situations.

We found that the esophagus was longer in males compared to females. Comparable studies elsewhere revealed conflicting studies. Awad et al. in their study on esophagus among normal control subjects and patients with esophageal disorders concluded that mean length of the esophagus, is not related to an individual's sex.

However Li et al. in his study in which candidates with achalasia were excluded noted that 96 males had a significantly longer mean esophageal length $(23.6+/-0.3$ $\mathrm{cm})$ than 116 females $(22.4+/-0.3 \mathrm{~cm})$. In his study Scapa et al. had similar conclusions, in which esophageal length was significantly longer in male patients. It thus suggests that interpretation of the length of the esophagus for various interventions requires that gender be considered.

Most studies like ours did not find any correlation between esophageal length and weight (Yang et al.; Scapa et al.; Li et al.).

Of the parameters considered, the individual's height was the parameter that best correlated with esophageal height. This finding is similar to that of several studies by other authors (Song et al.; Yang et al.; Scapa et al.; Awad et al.; Yau et al.; Staiano \& Clouse). Awad et al. in his analysis concluded that the length of the esophagus was related to the individual's height. Similar conclusions were made by Scapa et al., Song et al. and Yau et al. Yang et al. while studying the esophagus in children had similar conclusions on the effect of height. They derived an equation to estimate the length of the esophagus to be: $1.048+0.167 \mathrm{x}$ height (in centimeters).

However Omari et al. (1999) in a study in premature infants similarly worked out a formula for calculating esophageal length using a preterm infant's height.

We did not find any other study in literature that compares sterna length and esophageal length. However, esophageal length did not correlate with sterna length. Selthofer et al. (2006) found an average length of $18.29 \mathrm{~cm}$ in females and $20.86 \mathrm{~cm}$ in males. We found a comparable mean length of $19.75 \mathrm{~cm}$ when both sexes are combined.

In conclusion, most of our findings compare well with those of other authors. We did not find any significant correlation between the length of the esophagus and individual's weight, body mass index and sterna length. However, we did find that individual's height is the parameter that best correlates with the esophageal length.

KAISHA, O. W.; MUTIE, T. \& KIOKO, H. M. Correlación de la longitud del cuerpo esofágico con la medida de parámetros externos del organismo. Int. J. Morphol., 29(3):895-898, 2011.

RESUMEN: Hay desacuerdo en cuanto a si existe una correlación entre la longitud del cuerpo esofágico y la de varios parámetros corporales externos medibles. Esta longitud se ha observado que varía en diferentes estados de enfermedades del tracto 
gastrointestinal superior y entre distintas razas. Según la literatura consultada, ningún estudio de este tipo se ha publicado, en particular, entre una población de África y Kenia. El propósito de este estudio fue determinar cómo la longitud del esófago se correlaciona con diversos parámetros corporales externos. Se realizó un estudio observacional y transversal en la Unidad de Endoscopía del Hospital Nacional Kenyatta (KNH). Todos los pacientes sometidos consintieron a la la endoscopía digestiva alta (OGD) en KNH. Fueron evaluados 76 pacientes sometidos a endoscopía flexible. (43 eran hombres). La longitud promedio del esófago fue de 22,2 cm (DE 2,63). Los hombres tuvieron un esófago más largo que las mujeres. La longitud del esófago tuvo una correlación negativa con el peso del individuo y su índice de masa corporal. Hubo una correlación positiva entre la longitud del esófago en comparación con la altura de la persona y la longitud esternal. La altura individual es el parámetro que mejor se correlaciona con la longitud del cuerpo esofágico.

PALABRAS CLAVE: Longitud del esófago; Longitud esternal; Parámetros corporales.

\section{REFERENCES}

Awad, Z. T.; Watson, P.; Filipi, C. J.; Marsh, R. E.; Tomonaga, T.; Shiino, Y.; Bhatia, S. \& Boedefeld, W. 3rd. Correlations between esophageal diseases and manometric length: a study of 617 patients. $J$. Gastrointest. Surg., 3(5):483-8, 1999.

Bannister, L. H. The Gastrointestinal tract, in Gray's Anatomy. $38^{\text {th }}$ edition. Edinburgh, Churchill Livingstone, 2000. p. 1751 .

Li, Q.; Castell, J. A. \& Castell, D. O. Manometric determination of esophageal length. Am. J. Gastroenterol., 89(5):722-5, 1994.

Marshall, R. E.; Anggiansah, A.; Anggiansah, C. L.; Owen, W. A. \& Owen, W. J. Esophageal body length, lower esophageal sphincter length, position and pressure in health and disease. Dis. Esophagus, 12(4):297-302, 1999.

Omari, T. I.; Benninga, M. A.; Haslam, R. R.; Barnett, C. P.; Davidson, G. P. \& Dent, J. Lower esophageal sphincter position in premature infants cannot be correctly estimated with current formulas. J. Pediatr., 135(4):5225, 1999.

Scapa, E.; Broide, E.; Waron, M.; Klinowski, E. \& Eshchar, J. Esophagogastric mucosal junction (EGMJ): its location as measured by endoscopy. Surg. Laparosc. Endosc., 7(2):159-61, 1997.
Selthofer, R.; Nikolic’', V.; Mrcela, T.; Radic', R.; Leksan, I.; Rudez, I. \& Selthofer, K. Morphometric analysis of the sternum. Coll. Antropol., 30(1):43-7, 2006.

Song, T. J.; Kim, Y. H.; Ryu, H. S. \& Hyun, J. H. Correlation of esophageal lengths with measurable external parameters. Korean J. Intern. Med., 6(1):16-20, 1991.

Staiano, A. \& Clouse, R. E. Value of subject height in predicting lower esophageal sphincter location. Am. J. Dis. Child, 145(12):1424-7, 1991.

Teige, K. Morphometric studies of x-rays of the sternum. Z. Rechtsmed., 90(3):199-204, 1983.

Yang, G. S.; Bishop, W. P.; Smith, B. J.; Goudy, S. L.; Sato, Y. \& Bauman, N. M. Radiographic and endoscopic measurements of esophageal length in pediatric patients. Ann. Otol. Rhinol. Laryngol., 114(8):587-92, 2005.

Yau, P.; Watson, D. I.; Jamieson, G. G.; Myers, J. \& Ascott, $\mathrm{N}$. The influence of esophageal length on outcomes after laparoscopic fundoplication. J. Am. Coll. Surg., 191(4):360-5, 2000.

Correspondence to:

Wyckliffe Kaisha Otsianyi

Lecturer, Department of Human Anatomy

School of Medicine

University of Nairobi. P. O.

BOX 368-00202, Nairobi

P.O. Box 368-00202

Nairobi

KENYA

Tel: +254722217632 .

Email: wyksa2000@yahoo.com

Received: 29-12-2010

Accepted: 24-05-2011 